\title{
Analysis of synergy of the capital budgeting method and intellectual capital disclosure
}

\author{
N. Astrini, A.K. Wardini \& Z. Hidayah \\ Universitas Terbuka, South Tangerang, Indonesia
}

\begin{abstract}
The diminishing fossil energy reserve has forced Indonesia to prioritize renewable energy (RE) development through its energy resources. However, RE power plant companies in Indonesia are challenged by the doubtfulness of potential investors and developers concerning their profitability and sustainability. To address this issue, this study aims to analyze the synergy between the capital budgeting method and the disclosure of intellectual capital (IC) of a wind farm expansion project in increasing their investment viability. The data were collected through interviews and documentation. The interactive analysis was used in this study. It was found that both the capital budgeting method and IC disclosure mutually supported the analysis of investors by helping them take better investment decisions. However, future studies are required to analyze the presentation of IC disclosure in other RE plants to increase Indonesia's RE development funding opportunities.
\end{abstract}

Keywords: capital budgeting methods, intellectual capital disclosure, investment decisions, project funding, renewable energy.

\section{INTRODUCTION}

Energy crises arise when the available fuel reserves show a deficit compared to consumption needs. In such a case, the government will prevent the scarcity of energy by developing new renewable energy sources.

Funding for renewable energy (RE) power plants in Indonesia is one of the major factors that has hindered the development of the project. Adequate funding would overcome RE project obstacles such as inadequacy of technological mastery, human resources, and raw materials procurement. The investment decision of potential investors is strongly related to the success of obtaining funding. It was mentioned that capital budgeting and investor behavior influence the investor decisionmaking process (Ekawati, 2016). Investor behavior includes their psychological factors in dealing with investment risk, which is part of behavioral finance (Baker and Ricciardi, 2014). It was also explained that investment decisions are influenced by several financial drivers, namely, a rational evaluation of the economic opportunities of a project, and non-financial drivers related to the investor's background in terms of education and experience (Masini and Menichetti, 2013). These aspects have a chance to positively influence investor perceptions of a prospect of a project through non-financial information on its true value. In this case, it can improve the project funding opportunities and generate positive idealism, especially for RE power plant development in Indonesia.

Non-financial factors of RE projects in Indonesia, regarding their influence on investment decisions, should include several aspects related to the specific advantages of the project that are not revealed in financial factors. It can be shown in the intellectual capital (IC) of the project. IC is an intangible device that will provide value creation for a project with adequate management. Razafindrambinina and Anggreni (2011) explained the three components of IC, which are human capital, structural capital, and customer or relational capital. 
This study is focused on analyzing the synergy between the capital budgeting method and IC disclosure to obtain funding for the RE power plant in Indonesia, specifically funding for the windfarm expansion project. The problem formulation is about how the synergy between the capital budgeting method and the IC disclosure of windfarm expansion projects can increase investment viability for the project.

\section{METHOD}

This study employed a qualitative approach, and its framework is shown in Figure 1. The figure shows the interference of IC in investment decision making. IC disclosure is a non-financial factor that influences the ultimate goal of obtaining project funding.

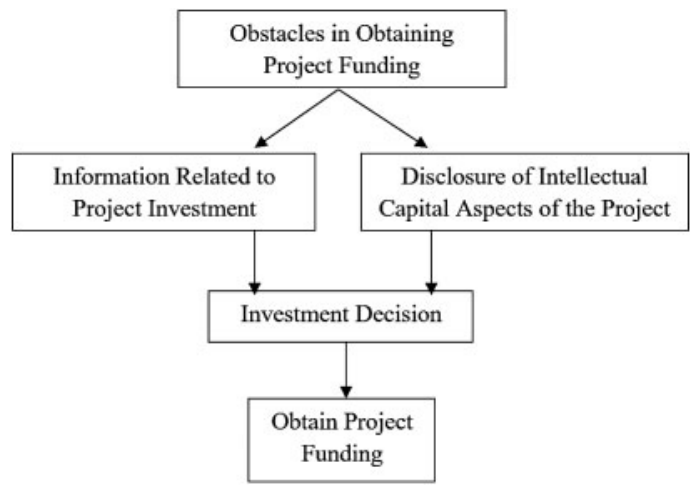

Figure 1. Framework.

The data were collected using semi-structured interviews and documentation after the key informants were selected using the purposive sampling method. The informants covered four different professions, namely, investor, head of development of the wind farm expansion projects, head of project finance, and lecturer.

Interactive analysis, which was developed by Miles and Huberman (2014), was adopted in this study. In this study, data reduction, presentation, and verification cycle would be repeated if the conclusion is still considered to be deficient, which requires additional data. It was conducted until the objectivity and validity of the data was reached. Thus, conclusions that can be accounted for were obtained.

\section{RESULTS AND DISCUSSIONS}

This study explained the mutually supporting relationship between the capital budgeting method and the disclosure of IC in increasing the investment viability. The interviews and documentation process revealed that the capital budgeting method played a huge role and was perceived to be effective in supporting the investment feasibility analysis of a project in certain industries and certain project characteristics. However, other factors were required as a broader perspective about investment opportunities for a project. The non-financial factors influence investment decisions but are not reflected in financial statements, especially the income statement. It could consist of environment impact management, employment, and others. The interview excerpts related to the abovementioned explanation were taken from informants who were investors, heads of project development, heads of project finance, and lecturers in the faculty of economics.

JS (2019) said that:

Actually, some investors also see 'additionality', meaning how it impacts, for example, social aspects, development, and the number of jobs created; for example, when we build power plants, 
how many people will be affected? $\mathrm{CO}_{2}$ reduction is also taken into account. The 'additionality' is more about the positive points of the project, which are not measured in profit. For example, $\mathrm{CO}_{2}$ is reduced, which is not measured in profit. Another example is the development of the local economy by carrying out a project. There may be a measure, but it is beyond economic returns.

In the financial model, an investor certainly wants to see how much the return is, how solid the model is, whether the model uses assumptions that make sense and are correct, its sensitivity, its tariff, and its selling price.

NP (2019) said that:

Starting from the FS, so we analyze the availability of resources, availability of technology, access, as well as eligibility for construction, then the risks associated with other things such as permitting, regulation, and then we determine its value in monetary terms, what it will be like. Then after that, a financial model is made that is projected for the next 30 years or during the operation of the project, to determine whether the project is profitable, or not to be developed, financed, and built, and it seems that the main parameter is still IRR.

We have Info Memo ... We display this Info Memo to relevant investors asking for funding after our FS is received.

IS (2019) said that:

There must be a financial model as a basis for later talking with PLN as a customer. The financial model must be attached because it will later reflect the ability of the project's payback period. The purpose is not only for investors but also for lenders.

The power purchase agreement (PPA) is one of the triggers to get financial close with investors. Whereas with PLN, PPA is important as a determining factor that the project can go ahead. The PPA stated how much should be invested in the project.

ME (2019) said that:

To attract investors ... hmmm ... feasibility study, because capital budgeting is only part of the feasibility study of a project, right? Budgeting is only a financial aspect, whereas there are other aspects that we must look at if we want to adopt a project. FS in terms of work culture is suitable. Tools to know whether a project is profitable or not must be seen from all aspects, there is a balanced scorecard, also financial models.

After reviewing several previous studies and interviewing several informants, the analysis result is shown in Figure 2.

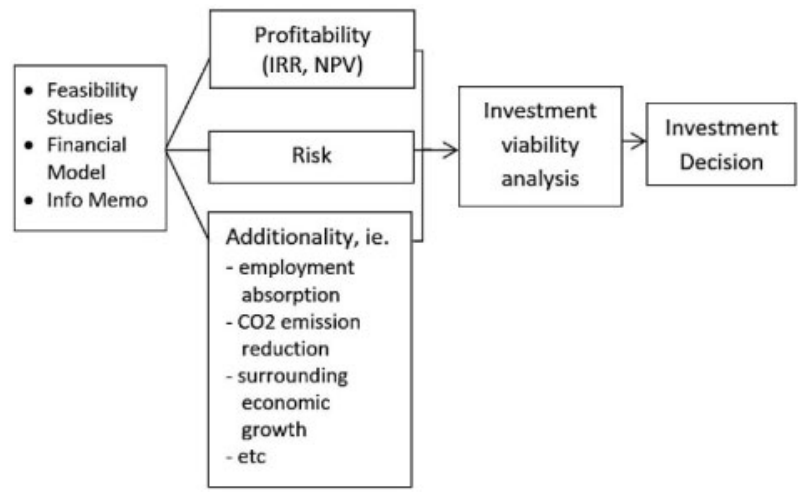

Figure 2. A synergy of the capital budgeting method and intellectual capital disclosure in increasing the investment feasibility of windfarm expansion projects.

In Figure 2, information obtained from feasibility studies (FS), financial model (FM), and information memorandum (IM) is in the form of financial and non-financial information. In this case, non-financial factors significantly reduced investment risk perception, which was not reflected in the financial statements. Both financial and non-financial information was valuable as an analysis 
material for investors in assessing the long-term investment feasibility of a project. In Figure 2, it is shown that the capital budgeting method represents the level of profitability. On the other hand, IC disclosure is presented as an aspect that influences the project's risk level preference and the project's positive impact information in 'additionality'.

In terms of investment decisions of the wind farm expansion project, FM, FS, and IM have a broader scope regarding financial and non-financial information. In FS and IM, several aspects of the IC were presented. There was information concerning the solutions to mitigate the project risks, the use of more efficient information technology systems, the relationship between project management and the central and the local government, and the method to approach the surrounding community. The results of the analysis are expected to help investors make better investment decisions.

\section{CONCLUSIONS AND RECOMMENDATIONS}

The financial and non-financial information obtained from FS, FM, and IN was valuable for investors in assessing the feasibility of project investment. The capital budgeting method is a financial aspect that represents the profitability or return on investment. On the other hand, IC disclosure is a non-financial aspect that influences the project risk level preference. The results of the analysis of financial and non-financial factors were mutually supportive and could help investors make better investment decisions.

It is suggested that further studies that analyze the IC disclosure on the RE industry project in Indonesia be conducted. Therefore, it could increase funding opportunities and improve RE development in Indonesia.

\section{REFERENCES}

Baker, H. Kent and Ricciardi, Victor. (2014). Investor Behaviour: The Phsycology if Financial Planning and Investing. New Jersey: John Wiley \& Sons, Inc.

Bruggen, Alexander, Vergauwen, Philipe and Dao, Mai. (2009). Determinants of Intellectual Capital Disclosure: Evidence from Australia. Journal of Management Decision, vol. 47 No.2, 2009. pp. 233-234.

Droj, L. (2016). Premises of Behavioral Finance in Rational Decision Making.The Annals of The University of Oradea Economic Sciences Journal, vol. 1 No. 1, pp. 671-681

Ekawati, Erni. (2016). Manajemen Keuangan. Jakarta: Universitas Terbuka.

Masini, Andrea and Menichetti, Emanuela. (2012). Investment Decisions in the Renewable Energy Sector: An Analysis of Non-Financial Drivers. Technological Forecasting and Social Change, vol. 80, No. 3, pp: $510-524$.

Miles, M. B., Huberman, A. M., \& Saldana, J. (2014). Qualitative Data Analysis: A Methods Sourcebook (3rd ed.). Thousand Oaks, CA: Sage.

Razafindrambinina, D. dan Anggreni, T. (2011). IC and Corporate Financial Performance of Selected Listed Companies in Indonesia. Malaysian Journal of Economic Studies, vol. 48 No. 1, pp. 61-77.

Sofian, Saudah dan Tayles, Mike E. dan Pike, Richard H. (2004). Intellectual Capital: An Evolutionary Change in Management Accounting Practices. Presentation at The Fourth Asia Pacific Interdiciplinary Research: Singapore. 